\title{
Content validity evidences in the motor coordination test with ball
}

\section{Evidências de validade de conteúdo do teste de coordenação motora com bola}

\author{
Schelyne Ribas ${ }^{1}$ \\ (D) https://orcid.org/0000-0001-7408-7784 \\ Layla Maria Campos Aburachid ${ }^{1}$ \\ (D) https://orcid.org/0000-0002-0116-9014 \\ Juan Carlos Pérez Morales² \\ (D) https://orcid.org/0000-0002-4497-5518 \\ Gabriella Nelli Monteiro ${ }^{3}$ \\ (D) https://orcid.org/0000-0001-6656-4560 \\ Gibson Moreira Praça ${ }^{2}$ \\ (D) https://orcid.org/0000-0001-9971-7308 \\ Henrique de Oliveira Castro ${ }^{4}$ \\ (D) https://orcid.org/0000-0002-0545-164X \\ Pablo Juan Greco ${ }^{2}$ \\ (D) https://orcid.org/0000-0003-2607-5935
}

Abstract - The main objective of this study was to establish content validity evidences in the Motor Coordination Test with Ball (MCTB). Four Ph.D. professors and former sports coaches with academic experience in the motor coordination area took part of the validation process as experts. The experts assessed four motor tasks and graded using the Likert scale from one to five for criteria of clarity of language, practice relevance, and theoretical relevance. The content validity coefficient (CVC) has been used to determine the CVCc of each task and the CVCt for the instrument as a whole, adopting as a cutoff CVCc .70 and CVCt .80 . The results showed good agreement among experts concerning "clarity of language" $(\mathrm{CVC}=.89)$, "practice relevance" $(\mathrm{CVC}=.81)$, and theoretical relevance $(\mathrm{CVC}=.86)$. For "practice relevance" of images and videos of task execution, there has been observed CVCt of .86 and CVCt of .95, respectively. When requested the order of relevance of coordination pressures, the agreement among experts presented the existence of at least four coordination pressures in each one of the tasks and, out of these, at least two had a higher relevance. After the calculation of the CVC, ecological validity was determined for the MCTB, accrediting it as an instrument for the assessment of motor coordination with ball in the context of sports games.

Key words: Sports; Psychomotor Performance; Validation studies.

Resumo - Objetivou-se estabelecer evidências de validade de conteúdo do Teste de Coordenação motora com bola (TCMB). Participaram como especialistas do processo de validação quatro professores doutores e ex-treinadores esportivos com experiência acadêmica na área da coordenação motora. Os especialistas avaliaram 4 tarefas motoras e atribuíram uma nota em uma escala tipo Likert de um a cinco pontos para os critérios de clareza de linguagem, pertinência prática e relevância teórica. Recorreu-se ao coeficiente de validade (CVC) para determinação do CVCc de cada tarefa e o CVCt para o instrumento como um todo, adotando como ponto de corte CVCc.70 e CVCt.80. Os resultados evidenciaram boa concordância dos especialistas quanto à "clareza de linguagem" (CVC $=.89)$, "pertinência prática" $(C V C=.81)$ e "relevância teórica" $(C V C=.86)$. Para a "pertinência prática" das figuras e vídeos de execução das tarefas, observou-se CVCt de .86 e CVCt de .95, respectivamente. Quando solicitada a ordem de relevância das pressöes coordenativas, a concordância entre avaliadores apresentou existência de ao menos quatro pressöes coordenativas em cada tarefa e destas ao menos duas pressões com maior relevância. Após o cálculo do CVC, determinou-se a validade ecológica do TCMB aprovando-o como um instrumento para a avaliação da coordenação motora com bola no contexto dos jogos esportivo.

Palavras-chave: Desempenho psicomotor; Esporte; Estudos de validação.
1 Universidade Federal do Mato Grosso. Cuiabá, MT. Brazil.

2 Universidade Federal de Minas Gerais. Belo Horizonte, MG. Brazil.

3 Faculdade Centro Mato-Grossense. Sorriso, MT. Brazil.

4 Centro Universitário Instituto de Educação Superior de Brasília- IESB. Ceilândia, DF. Brazil. Faculdade Anhanguera de Ciência e Tecnologia de Brasília - FACITEB. Brasília, DF, Brazil.

Received: March 24, 2020 Accepted: August 28, 2020

How to cite this article Ribas S, Aburachid LMC, Morales JCP, Monteiro GN, Praça GM, Castro HO, Greco PJ. Content validity evidences in the motor coordination test with Ball. Rev Bras Cineantropom Desempenho Hum 2020, 22:e72376. D0l: http://dx.doi. org/10.1590/1980-0037.2020v22e72376.

Copyright: This work is licensed under a Creative Commons Attribution 4.0 International License. 


\section{INTRODUCTION}

The capacity of executing several gestures or motor actions, frequently described as motor competence, is a pre-requisite to a pleasant and wellsucceeded participation in everyday, leisurable, and playful activities, whether it is during childhood, adulthood, or elder age ${ }^{1}$. Motor competence refers to the degree of qualified development in a toll of tasks, as well as coordination and motion control to be performed ${ }^{2,3}$.

In the last decade, researches that investigated competence or motor development measured the construct motor coordination in children and teenagers relating them to several variables aiming to point the main factors that positive- and negatively influence the development ${ }^{4-7}$.

Although, when motor coordination is assessed in the context of team sports games, we have verified the necessity of diagnostic instruments that consider situational and environmental factors in an individual sports life, either at school or during the process of training in the stages of forming or performing.

Despite the existence of an instrument qualified as a gold pattern to assess the development and motor coordination, nowadays, there are in literature, multiple instruments that have been proposed in different areas of The Science of Sport: the Test of Gross Motor Development (TGMD2), Movement Assessment Battery for Children, 2nd edition (MABC-2), Körperkoordinationstest Für Kinder (KTK), Bruininks-Oseretsky Test of Motor Proficiency, 2nd Edition (BOT-2), Motor Development Scale (MDS), Basic Motor Competencies Assessment-MOBAK and the Motor Coordination Test with Ball- TECOBOL among others ${ }^{8-11}$.

Although both national and international literature refer to these instruments to detect the coordination level in children and teenagers, most of the aforementioned tests have a restrict application in our country, for not presenting standards and classifications for Brazilian children or for not using tasks with balls or because they request motor skills used in several team sports. Due to the lack of tests to specifically assess motor coordination with ball, validated for a Brazilian cutoff sample, this paper starts the process of content creation and validation of the Motor Coordination Test with Ball (MCTB), specific test for the detection of the level of motor coordination with ball in a sample with Brazilian kids between ten and twelve years old. The theoretical underpinning for the MCTB links to the model of pressure demands for the coordination movement formulated by Roth in 1998. The MCTB presents dynamic tasks with different balls (hand-foot) that request motor skills that are part of sports games (dribble /guiding, reception, etc.) in which it assesses motor coordination with ball under combined action of coordination pressures (time, precision, simultaneity, sequence, variability, burden) as indicated by the authors of this model.

The initial process of instrument validation concentrates in the procurement of ecological validity of the instrument through the CVC, the 
Content Validity Coefficient ${ }^{12,13}$. This calculation has been widely used to measure ecological validity of instruments in different areas in the science of sports and allows to previously examine if the actual instrument measures, regarding the content, the construct that it intends to measure ${ }^{14-19}$.

For this matter, by considering the inexistence of an instrument that assesses the coordination performance with ball, and building it upon a theoretical model that proposes that every coordinated action is related to the combination of demands of pressure, it is justified and consequently, in a pedagogical perspective, aims to develop and present validation evidences of a test to assess motor coordination with ball, the MCTB.

\section{METHOD}

\section{Participants}

Four experts $(n=4)$ from public college education institutions from different regions in Brazil took part in this research. For the selection, having a doctoral degree was a criterion, not having previously participated in none of the parts of this research process, experience as a coach and/or as a professor in the area of sports and experience with the proposed topic for at least ten years ${ }^{20}$. Participants signed an informed consent form prior to the commencement of the study. This study was approved by the local ethics committee.

\section{Construction Process of the Instrument}

The Motor Coordination Test with Ball (MCTB) assesses the level of motor coordination with ball for kids and teenagers, from both genders, in the 10-12 age group. The choice of age relates to concepts derived from the area of motor development that points this age group as the time to start the specialization of sports disciplines, which implicates a teachinglearning-training process of specific skills and a consequent targeting of coordination activities, according to the choice. Besides, the instrument was built based on a model of coordination demands of pressure for the coordination movement, elaborated by Kroger and Roth. The MCTB compounds four tasks, performed with hand/foot using left sides and/ or right sides of the body, using fundamental motor skills that are parts familiar to invasion team sports practice (kicking, conducting, throwing, and receiving), under the influence, for at least four out of the six demanded coordination pressure demands (time, precision, sequence, Simultaneity, variability, and burden). The profile of coordination demand changes according to the characteristics of requested skills by the tasks, that way, besides the existing coordination pressures, there is relevance of these during the execution of the task, as observed in box 1.

Among the coordination pressures that cause the highest influences or representativeness in the tasks, according to experts, are: Task 1 (time, precision, and Simultaneity); Task 2 (time, precision, and Simultaneity); Task 3 (time and precision); Task 4 (time, sequence, and Simultaneity). 
Box 1. Motor skills and pressure demands requested for the execution of the MCTB tasks.

\begin{tabular}{|lcccccc|}
\hline \multicolumn{7}{|c|}{ Coordination pressure demands } \\
\hline $\begin{array}{l}\text { Tasks and } \\
\text { Motor Skills }\end{array}$ & Time & Precision & Sequence & Simultaneity & Variability & Burden \\
\hline T1 Bouncing/Guiding & $X^{1}$ & $X^{1}$ & $X$ & $X^{1}$ & $X$ & $X$ \\
T2 Bouncing & $X^{1}$ & $X^{1}$ & & $X^{1}$ & & $X$ \\
T3 Guiding & $X^{1}$ & $X^{1}$ & $X$ & & $X$ \\
T4 Throwing/receiving & $X^{1}$ & $X$ & $X^{1}$ & $X^{1}$ & $X$ \\
\hline
\end{tabular}

Note. $\mathrm{T} 1$ to $\mathrm{T} 4=$ tasks 1 to $4 ; \mathrm{X}=$ existing pressure in tasks and $\mathrm{X}^{1}=$ protagonist pressures in tasks.

\section{Application process and Instrument Validation}

Initially, we invited and informed the experts about all the items in the research through e-mail. Then, for those who accepted the invitation, we forwarded the Informed Consent Form clarifying that each participation was voluntary, anonymous, non-paid, and that information concerning the research was strictly academic. The assessment of the MCTB manual by the experts happened through a form by Google Docs. It contained the description of the tasks, the images of the courses of the tasks, and the videos that exemplified the detailed performance of each task. The form became available online for five weeks so that the experts could fill it in.

The procedures of content validation of the MTCB followed the guidelines provided by Hernández-Nieto ${ }^{13}$. Experts graded using the five-point Likert Scale (1- meaning inadequate and 5- meaning totally adequate) to classify tasks as clarity of language- CL (language and description in the items), practice relevance- PR (it considers if each item was elaborated to assess the concept of interest), and theoretical relevance- TR (relevance regarding the item expressed and its consistency and theoretical importance). When it came to the validation via analysis of images and videos of the tasks, experts assessed these ones as its practice relevance. In the process of validation, the experts made additional comments about the description and performance of the tasks, images and videos on the performance of the tasks that allowed further adjustments. Besides the three assessed subitems, we requested the experts to point, in a descending order, the relevance of the coordination pressure demands in each task. After filling in and receiving the validation of instrument forms from all the experts, we have put data in a spreadsheet in Microsoft Office Excel 2013 for further analysis.

\section{Data analysis}

The answers from experts were entered and analyzed in the Microsoft Office Excel 2013 software using the CVC formula. Data analysis was computed based on specific formulas for CVC calculation ${ }^{13}$ and is presented as follows:

- The average scores of each item $(M x)$ was first calculated based on scores assigned by experts. In the calculation, $\Sigma x i$ represents the sum of experts' scores and J represents the number of experts who evaluated the item: 


$$
M_{x}=\frac{\sum_{i=1}^{J} x_{i}}{J}
$$

Using the average as basis, $\mathrm{CVC}$ was calculated for each item $\left(C V C_{i}\right)$, where $V \max$ represents the maximum value that the item could receive:

$$
C V C_{i}=\frac{M_{x}}{V_{\text {máx }}}
$$

In order to discount possible biases of evaluators, the error $(P e i)$ was calculated for each item:

$$
P e_{i}=\left(\frac{1}{J}\right)^{J}
$$

The final CVC of each item $(C V C)$ was also calculated:

$$
C V C_{c}=C V C_{i}-P e_{i}
$$

In the calculation of the total CVC $\left(C V C_{t}\right)$, for each of the characteristics / subitems (clarity of language-CL, practical relevance-PR and theoretical relevance-TR):

$$
C V C_{t}=M c v c_{i}-M p e_{i}
$$

In the formula, the mean CVCs values of the test items are represented by $M c v c_{i}$ and the mean error of the test items by $M p e_{i}$. The total CVC $\left(C V C_{t}\right.$ ) refers to the value calculated for the instrument in general, that is, the average value calculated for all items referring to clarity of language, practical relevance and theoretical relevance. The cutoff sampling adopted for clarity of language, practice relevance and theoretical relevance was $\mathrm{CVC}_{\mathrm{c}}$ $\geq .71$ for each task and $\mathrm{CVC}_{\mathrm{t}} \geq .81$ for the whole instrument. According to literature, these indices are considered adequate for the process of content validation ${ }^{13}$. Besides the CVC, we have applied the Interobserver Agreement calculation (IOA) in order to define the objectivity of answers as for the existence and relevance of coordination pressures in each task. The formula to estimate it is (IOA = agreements / (agreements + disagreements). The closer to $1.0(100 \%)$ the higher the level of interobserver agreement and $.75(75 \%)$ is the minimum acceptable agreement value in literature ${ }^{21}$.

\section{RESULTS}

We have presented the results obtained in the Content Validity Coefficient (CVC) calculation for the analyzed variables in Table 1.

When it comes to clarity of language (CL) the indices of $\mathrm{CVC}_{\mathrm{c}}$ vary between .85 and .90 and the $\mathrm{CVC}_{\mathrm{t}}=.88$. Despite the fact that the tasks present higher indices than the recommended cutoff by literature, we have made some adjustments referring to the rules of the Portuguese language 
regarding the description of the tasks. According to the experts, the justification for those adjustments aim to facilitate the understanding of the actions assessed while using the instrument. As for practice relevance of the tasks, we have verified that all tasks reached values of $\mathrm{CVC}_{\mathrm{c}}$ between .75 and .90 and the $\mathrm{CVC}_{\mathrm{t}}=.85$. Finally, when we analyzed the results from theoretical relevance of the tasks, we have identified that all tasks reached $\mathrm{CVC}_{\mathrm{c}}$ values between .75 and .95 and the $\mathrm{CVC}_{\mathrm{t}}=.90$. Regarding these three items (CL, $\mathrm{PR}$, and TR) the indices were higher than recommended by literature ( $\geq .71)$. When it came to the assessment of practice relevance of images and videos from the performance of tasks, we have observed $\mathrm{CVC}_{\mathrm{c}}$ between .86 and .90 ; $\mathrm{CVC}_{t}$ of .86 and $\mathrm{CVC}_{c}$ between .91 and .96 and $\mathrm{CVC}_{t}$ of .95 , respectively.

Regarding relevance and hierarchy of coordination demands of each task, we have verified, through the IOA, that only Task 3 presented two coordination pressure demands acting as a protagonist. For other tasks, the leading role was verified in three pressures, as presented in Table 2.

The results of the IOA expressed minimum values of .75 (75\%) and maximum of $1.0(100 \%)$ for existence and relevance of coordination pressures under the tasks. In Task 3, though, there was no agreement of 1.0 (100\%) for pressure of sequence movements, although, this conflict is not expressive, given the percentage of agreement among most of the experts involved .75 (75\%). Pressures that carry leading roles in the tasks are Task 1 (time, precision, and Simultaneity); Task 2 (time, precision, and Simultaneity); Task 3 (Precision and Simultaneity); Task 4 (time, sequence, and Simultaneity).

\section{DISCUSSION}

This study aimed to establish evidences of content validity in the Motor Coordination Test with Ball (MCTB). According to the assessment of the

Table 1. Calculation of CVCc and CVCt for clarity of language, practice relevance and theoretical relevance of the tasks that compose the MCTB.

\begin{tabular}{|c|c|c|c|c|c|c|c|c|c|}
\hline & \multicolumn{3}{|c|}{$\begin{array}{c}\text { Clarity of } \\
\text { Language (CL) }\end{array}$} & \multicolumn{3}{|c|}{$\begin{array}{c}\text { Practice } \\
\text { Relevance (PR) }\end{array}$} & \multicolumn{3}{|c|}{$\begin{array}{c}\text { Theoretical } \\
\text { Relevance (TR) }\end{array}$} \\
\hline Tasks & CVCt & CVCc & Pei & CVCt & CVCc & Pei & CVCt & CVCc & Pei \\
\hline $\mathrm{T} 1$ & \multirow{4}{*}{.88} & .90 & \multirow{4}{*}{.0039} & \multirow{4}{*}{.85} & .90 & \multirow{4}{*}{.0039} & \multirow{4}{*}{0.90} & .95 & \multirow{4}{*}{.0039} \\
\hline T2 & & .90 & & & .90 & & & .95 & \\
\hline T3 & & .90 & & & .75 & & & .75 & \\
\hline T4 & & .85 & & & .85 & & & .95 & \\
\hline
\end{tabular}

Note. T1 to T4= tasks 1 to 4; CVCt - Content Validity - total; CVCc - Content Validity - for each task; MTCB - Motor Coordination Test with Ball; Pei - calculation of error.

Table 2. Interobserver Agreement calculation (IOA) for coordination demands for the tasks from the MCTB.

\begin{tabular}{lcccccc}
\hline \multicolumn{5}{c}{ Coordination Pressure Demands } \\
\hline Tasks & Time & Precision & Sequence & Simultaneity & Variability & Burden \\
\hline T1 & $1.0^{*}$ & $1.0^{*}$ & 1.0 & $1.0^{*}$ & 1.0 & 1.0 \\
T2 & $1.0^{*}$ & $1.0^{*}$ & - & $1.0^{*}$ & 1.0 & 1.0 \\
T3 & $1.0^{*}$ & $1.0^{*}$ & 0.75 & - & - & 1.0 \\
T4 & $1.0^{*}$ & 1.0 & $1.0^{*}$ & $1.0^{*}$ & - & 1.0 \\
\hline
\end{tabular}

Note. $\mathrm{T} 1$ to $\mathrm{T} 4$ = tasks from 1 to 4 ; ${ }^{*}$ protagonist pressures under the tasks. 
experts, the $\mathrm{CVC}$ calculated for clarity of language $\left(\mathrm{CVC}_{\mathrm{t}}=.88\right)$, practice relevance $\left(\mathrm{CVC}_{\mathrm{t}}=.85\right)$ and theoretical relevance of the tasks $\left(\mathrm{CVC}_{\mathrm{t}}=.90\right)$ is satisfactory in comparison to the proposal of the assessment of motor coordination with ball by the use of the $\mathrm{MCTB}$, once it presents indices referred in literature ${ }^{13}$. Therefore, after the calculation of the CVC, this research has confirmed the content validity for the MCTB for all the four tasks that are part of this test.

It is possible to observe, in specialized literature, that the development of instruments for the assessment of motor performance as a whole lacks objective procedures to establish validity of content, which justifies the use of the CVC as an essential procedure to accomplish, in a proper way, all the psychometric steps proposed when elaborating the instruments.

During the validation process of the Test of Gross Motor Development $(\text { TGMD-2) })^{18}$ and the Coordination Test with Ball (TECOBOL ${ }^{11}$ we have used the CVC to investigate the evidences of content validity of the chosen instruments. The value calculated for clarity of language, theoretical relevance and representativeness was $=.96$ and $\geq .90$, respectively, which confirms the instruments importance to measure motor development in children.

In the scale for assessment of procedural tactical knowledge in team sports games of invasion proposed for soccer, the CVC calculation for clarity of language was $\mathrm{CVC}_{\mathrm{t}}=.81$ and for practice relevance was $\mathrm{CVC}_{\mathrm{t}}=$ .80. This same scale applied in futsal a $\mathrm{CVC}_{\mathrm{t}}=.81$ for clarity of language and $\mathrm{CVC}_{\mathrm{t}}=.87$ for practice relevance and, in handball values were $\mathrm{CVC}_{\mathrm{t}}$ $=.80$ for clarity of language and $\mathrm{CVC}_{\mathrm{t}}=.94$ for practice relevance $22-24$. The tactical procedural knowledge test in basketball (TPKT-Bb) ${ }^{25}$, the results confirm that, for the purposes of language clearness $(\mathrm{CVCt}=.94)$ and practical relevance $(\mathrm{CVC} t=.91)$, the proposed items present satisfactory psychometric properties. Were presented evidence of content validity regarding the sport-oriented test of procedural tactical knowledge, through content validity, the $\mathrm{CVC}$. The results substantiated $\mathrm{CVC}_{\mathrm{t}}=.83$ for clarity of language, $\mathrm{CVC}_{\mathrm{t}}=.91$ for practice relevance, and $\mathrm{CVC}_{\mathrm{t}}=.95$ for theoretical relevance, which experts classified it as in "good agreement" 26.

The CVC as a source of evidence regarding content validity for the declarative tactical knowledge test in tennis and in volleyball, respectively ${ }^{14,15}$. Considering that the process of development and validation of the instrument included the use of scenes or images for the declarative tactical knowledge assessment, the $\mathrm{CVC}_{\mathrm{t}}$ for tennis and volleyball, respectively, was calculated to determine clarity of image $\left(\mathrm{CVC}_{\mathrm{t}}=.89 ; \mathrm{CVC}_{\mathrm{t}}=.92\right)$, practice relevance $(\mathrm{CVCt}=.91 ; \mathrm{CVCt}=.96)$ and image/item representativeness $\left(\mathrm{CVC}_{\mathrm{t}}=.98\right.$; $\left.\mathrm{CVC}_{\mathrm{t}}=.96\right)$. In this case, the calculation of $\mathrm{CVC}$ enabled to select, in an objective way, the most representative and adequate images, accordingly, in order to measure declarative tactical knowledge of tennis players.

During adaptation and validation of the Sport Multidimensional Perfectionism Scale-2 (SMPS-2) (CVC >.80), from the Basic Psychological Needs in Exercise Scale (BPNES) questionnaire (CVC>.81) and Leisure Practices Scale 
(EPL, in Portuguese) (clarity of language $\mathrm{CVC}_{\mathrm{t}}=.88$; practice relevance $\left.\mathrm{CVC}_{t}=.87\right)$ for a Brazilian context, the authors emphasized that the Portuguese version contain clear and relevant questions ${ }^{16,27,28}$.

In this perspective, the CVC configures as a renowned analysis and, utilized in different areas for content validity of instruments, the results of clarity of language, practice relevance, and theoretical relevance obtained in this study, as well as other aforementioned instruments, present scores that are higher than the cutoff classified as in "good agreement", resulting in a satisfactory content validity, which allows the continuation of the validation process ${ }^{12,13,20}$.

As for the Interobserver Agreement (IOA) regarding quantity and representativeness of coordination demands of tasks, this study has verified a $25 \%$ conflict in the answers given by the experts concerning the very Task 3. According to literature, this percentage is acceptable, and the remaining 75\% assume a qualification of in "good agreement" in the "experts" answers $^{21}$. In the validation process of the declarative tactical knowledge test in tennis, the authors have chosen to increase the minimum acceptable score, $80 \%$ IOA, when dealing with scenes from videos analyzed by the experts $^{14}$. Considering the non-use of IOA for the analysis of agreement among appraisers in motor performance tests, this discussion was limited to consider only the aforementioned study.

\section{CONCLUSION}

By observing the results obtained concerning content validity of the MCTB, we have concluded that this instrument attends clarity of language, practice relevance, and theoretical relevance, presenting good indices of CVCt and ecological validity. Thereafter, this study considers as finished the first stage of the validation process of a test allowing the continuity of the study with further analysis to soon be integrated in this process, considering the instrument's target population (children and teenagers between 10 and 12 years old). Other analysis must be conducted so it can be effectively said this instrument is valid as well os its construct, or further types of validity (criterion, predictive, construct, and others), according to researchers' objective in further studies. We believe the application of the instrument will allow the execution of psychometric analysis to confirm the dimensionality of the instrument through the gathering of the tasks related to similarity of motor skills and pressure coordination demands, which reinforces the theoretical model we have used. We understand that the content validity of the MCTB for students between 10 and 12 years old restricts the use of the tool, however, we expect that in further studies there will be amplification of assessments in other Brazilian regions and, perhaps, these will carry out new validation process with different age groups.

For that matter, the MCTB is presented as a guiding instrument in the teaching-learning-training process, for the motor coordination with ball 
content in a sports context, either at school or sports initiation. Besides, the MCTB is also a new academic tool, and helps the development of scientific knowledge production concerning the area.

\section{Acknowledgments}

The authors are grateful the Pró-Reitoria de Pesquisa of Universidade Federal de Minas Gerais and Universidade Federal do Mato Grosso.

\section{COMPLIANCE WITH ETHICAL STANDARDS}

\section{Funding}

This research did not receive any specific grant from funding agencies in the public, commercial, or no-profit sectors.

\section{Ethical Aspects}

The ethical approval was obtained from the Human Research Ethics Committee by the Universidade Federal de Minas Gerais and obtained consolidated report number 2.017.967/ 2017, and the protocol was written according to patterns established by the Declaration of Helsinki.

\section{Conflict of interest statement}

The authors have no conflict of interests to declare.

\section{Author Contributions}

Conceived and designed the experiments: PJG, SR, JCPM, LMCA, GMP, and HOC. Performed the experiments: PJG, SR, GNM, and LMCA. Analyzed the data: PJG, SR, JCPM, GNM and GMP. Contributed reagents/materials/analysis tools: PJG, SR, HOC and GMP. Wrote the paper: PJG, SR, JCPM, LMCA, GMP, HOC, GNM. All of the authors have read and approved the final version of this research.

\section{REFERENCES}

1. Barnett LM, Ridgers ND, Salmon J. Associations between young children's perceived and actual ball skill competence and physical activity. J Sci Med Sport 2015;18(2):167-71.

2. Kröger C, Roth K. Escola da Bola - Um Abc para Iniciantes nos Jogos Esportivos - 2a Ed. Phorte editora: São Paulo; 2005.

3. Rudd J, Butson ML, Barnett L, Farrow D, Berry J, Borkoles E, et al. A holistic measurement model of movement competency in children. J Sports Sci 2016;34(5):477-85.

4. Caçola P, Ibana M, Ricard M, Gabbard C. Children with developmental coordination disorder demonstrate a spatial mismatch when estimating coincident-timing ability with tools. Res Dev Disabil 2016; 48:124-31.

5. D'Hondt E, Deforche B, Gentier I, Verstuyf J, Vaeyens R, De Bourdeaudhuij I, et al. A longitudinal study of gross motor coordination and weight status in children. Obesity 2014; 22(6):1505-11.

6. Luz, LGO, Teixeira AFS, Santos R, Padez C, Ferreira JP, Silva, MJC. Association between BMI and body coordination test for children (KTK). A meta-analysis. Rev Bras Med Esporte 2015;21(3):230-235. 
7. Vandorpe B, Vandendriessche J, Vaeyens R, Pion J, Matthys S, Lefevre J, et al. Relationship between sports participation and the level of motor coordination in childhood: a longitudinal approach. J Sci Med Sport 2012;15(3):220-205.

8. Ferreira L, Vieira JLL, Rocha FF, Silva PN, Cheuczuk F, Caçola P, et al. Percentile curves for Brazilian children evaluated with the Bruininks-Oseretsky Test of Motor Proficiency, 2nd edition. Rev Bras Cineantropom Desempenho Hum 2020; 22:e65027.

9. Herrmann C, Gerlach E, Seelig H. Development and Validation of a Test Instrument for the Assessment of Basic Motor Competencies in Primary School. Meas Phys Educ Exerc Sci 2015;19(2):80-90.

10. Rosa Neto F. Manual de Avaliação Motora. 3rd ed. Florianopolis: DIOESC; 2015.

11. Silva SA, Zampier JELC, Silva FL. Valores de referência da coordenação com bola. Rev Acta Bras Mov Hum 2016;6(3):28-39.

12. Pasquali L. Validade dos testes psicológicos: será possível reencontrar o caminho? Psicol Teor Pesqui 2007;23:99-107.

13. Hernández-Nieto R. Contributions to Statistical Analysis: The Coefficients of Proportional Variance, Content Validity and Kappa [Internet]. book, Mérida: Universidad de Los Andes; 2002.

14. Aburachid LMC, Morales JCP, Greco PJ. Test Validation Process of Tactical Knowledge in Tennis: the Influence of Practice Time and Competitive Experience. Int J Sport Sci 2013;2013(1):13-22.

15. Costa GDCT, Castro HO, Cabral FA, Morales JCP, Greco PJ. Content Validity of scenes of the Declarative Tactical Knowledge Test in Volleyball-DTKT : Vb. Rev Bras Cineantropom Desempenho Hum 2016;18(6):629-37.

16. Nascimento Junior JRA, Vissoci JRN, Lavallee D, Vieira LF. Adaptation and validation of the Sport Multidimensional Perfectionism Scale-2 (SMPS-2) for the Brazilian sport context. Motriz: Rev Educ Fis 2015;21(2):125-36.

17. Quinaud RT, Backes AF, Silva DC, Nascimento JV, Ramos V, Milistetd M. Construction and content validity of the coaches' knowledge and competence questionnaire - CKCQ. Rev Bras Cineantropom Hum 2018;20(3):318-31.

18. Valentini NC. Validity and reliability of the TGMD-2 for Brazilian children. J Mot Behav 2012;44(4):275-80.

19. Valentini NC, Barbosa MLL, Villwock G, Pick RKK, Spessato BC, Balbinotti MAA, et al. Teste de Desenvolvimento Motor Grosso: Validade e consistência interna para uma população Gaúcha. Rev Bras Cineantropom Hum 2008;10(4):399-404.

20. Balbinotti MAA, Benetti C, Terra PRS. Translation and validation o the GrahamHarvey survey for the Brazilian context. Int J Manag Financ 2007;3(1):26-48.

21. Stemler SE. A comparison of consensus, consistency, and measurement approaches to estimating interrater reliability. Pract Assess Res Eval 2004;9(4):1-19.

22. Morales JCP, Aburachid LMC, Greco PJ. Escala para avaliação do conhecimento tático processual nos jogos esportivos coletivos de invasão: validação do conteúdo no futsal. FADEUP, editor. Rev Port Ciências Desporto 2011;11(4):71-2.

23. Morales JCP, Aburachid LMC, Greco PJ. Escala para avaliação do conhecimento tático processual nos jogos esportivos coletivos de invasão: validação do conteúdo no futebol. Rev Port Ciências Desporto 2011;11(4):70-1.

24. Morales JCP, Aburachid LMC, Greco PJ. Escala para avaliação do conhecimento tático processual nos jogos esportivos coletivos de invasão: validação do conteúdo no handebol. Rev Port Ciências Desporto 2011;11(4):72-4.

25. Morales JCP, Greco PJ, Andrade RL. Validade de Conteúdo do Instrumento para Avaliação do Conhecimento Tático Processual no Basquetebol. Cuad Psicol Deporte $2012 ; 12(1): 31-6$.

26. Greco PJ, Morales JCP, Aburachid LMC, Silva SR. Validity evidence of procedural tactical knowledge test for sports guidance. Rev Bras Educ Fís Esporte 2015;29(2):313-24. 
27. Andrade RD, Schwartz GM, Tavares GH, Pelegrini A, Teixeira CS, Felden ÉPG. Validade de construto e consistência interna da Escala de Práticas no Lazer (EPL) para adultos. Cien Saude Colet 2018;23(2):519-28.

28. Costa LCA, Maroco J, Vieira LF. Validation of the Basic Psychological Needs in Exercise Scale (Bpnes). J Phys Educ 2017;28(1):1-8.

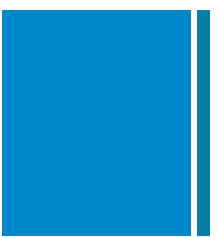

\section{Corresponding author}

Schelyne Ribas

Universidade Federal do Mato Grosso. Faculdade de Educação Física,

Campus Cuiabá.

Av. Fernando Correa da Costa 2367- CEP: 78060-900 Cuiabá,

Mato Grosso, Brasil.

E-mail: schelys@hotmail.com 